\title{
BIOSYSTEMATIC STUDIES OF SPERGULARIA MEDIA AND S. MARINA IN THE NETHERLANDS I. THE MORPHOLOGICAL VARIABILITY OF S.MEDIA*
}

\author{
A. A. STERK \\ Hugo de Vries-Laboratorium, Universiteit van Amsterdam
}

\section{SUMMARY}

The present paper, the first of a series of four on the biosystematics of the Dutch halophilous species of Spergularia, reports the results of a study of the morphological variability of $\boldsymbol{S}$. media by means of a number of population samples from all parts of the Dutch area, supplemented by the rearing of plants from seed samples in the experimental garden.

The seeds of $S$.media are usually winged, but in the area of the Dutch North Sea Islands, sometimes populations are encountered containing up to $70 \%$ plants with exalate to subalate seeds.

The development of the seed wing is chiefly determined by genetic factors, but to some extent modifiable by different environmental conditions. The seed wing is too variable to be of decisive diagnostic value to distinguish S.media from S.marina. Plants with exalate to subalate seeds produce seedlings that are significantly smaller than the seedlings of plants with broadly winged seeds. Fruit- and calyx lengths vary too widely to be of diagnostic value either.

The number of stamens plus staminodes is usually 10 , rarely 9 ; the number of fertile stamens is 8 to 10 in nearly all flowers of a population, but may be as low as $\mathbf{0}$ to $\mathbf{3}$ per flower in some individual plants. The number of fertile stamens is primarily determined by genetic factors. The growth habit and the vegetative characters appear to exhibit only phenotypic variation.

\section{INTRODUCTION}

The distinction between the taxa Spergularia media (L.) C. Presl [S.marginata (DC.) Kittel] and S.marina (L.) Griseb. (S. salina J. et C. Presl) has in the past often caused difficulties. Along the Dutch coast specimens occur which clearly exhibit the supposedly characteristic features of one of the two taxa, but also individual plants are reported with characters of both species (WESTHOFF 1947; WESTHOFF \& BROUWER 1951). The incidence of so-called "intermediate forms" was mentioned as early as 1870 by HoLKEMA and this induced him to follow MARSSON's (1869) suggestion to combine the two halophilous taxa of the genus Spergularia into one species, under the name of S.halophila Marss.

In the most recent Dutch excursion floras we find two points of view. According to Heukels-van OostSTRoOM (1962) there are two indigenous halophilous species, viz., Spergularia marginata (DC.) Kittel and S. salina J. et C. Presl, but in Heimans, Heinsius \& ThiJsse (1965) three halophilous species are recognised: S.marginata, S.salina and S.media Fr. The manifest taxonomic

- Published with financial aid from the Brumundfonds of the Royal Botanical Society of the Netherlands. 
problems associated with the specific delimitation of the halophilous spurreys of our salt marshes suggested a biosystematic approach.

There is a rather extensive literature regarding the taxonomy and the distribution of these halophilous species of Spergularia in western Europe, in which $S$.media and $S$ marina are described as polymorphous taxa showing a considerable degree of similarity through convergence. Their morphological similarity has led to very diverse opinions on the taxonomic distinctness of the two species and sometimes even to descriptions of "new" species; their polymorphy on the other hand has resulted in the recognition of several infraspecific taxa of both species. One thing and another led to a very confused nomenclature especially in the older literature. The occurrence of hybrids is reported in more recent publications (e.g., by RoTHMALER 1963 and HeGi 1964), and suspected hybridisation is mentioned by LAwalree (1952) and by ClaphaM c.s. (1962).

Special mention must be made of the studies by MONNIER $(1953,1955,1960 \mathrm{a}$, $1960 \mathrm{~b}, 1962$ ) who persued an extensive biotaxonomic investigation of the species of Spergularia in the western Mediterranean area, and by RATTER $(1959,1964$, 1965) who carried out a karyogenetic analysis of European and North African representatives of the genus.

Many of the experimental results mentioned in the present paper and in the forthcoming ones of this series have already been treated in greater detail by the author (STERK 1968). For a discussion of the nomenclatural arguments in favour of the selection of the binomials S.media (L.) C. Presl and S.marina (L.) Griseb. the reader is referred to the same paper.

\section{MORPHOLOGICAL VARIATION}

\subsection{Methodology}

The description of the variation in S.media and S. salina is always based on a detailed analysis of local populations. For population studies on a geographical and an ecological basis not only a knowledge of the characters and character complexes present in each population is required, but also an estimation of their relative frequencies of occurrence in that population. Studies of variation in populations were always based on an adequate number of systematically collected samples ("mass collections").

The populations studied in the Netherlands included:

1. populations from all main parts of the distributional area;

2. populations from the principal types of environment in order to detect possible correlations between variability and habitat; and

3. populations from sites where only one of the species occurred and from sites where the two grow together so as to acquire some insight into possible hybridisation and introgression phenomena between $S$. media and S. salina, if any. The variation recorded in this way being of a phenotypical nature, the possible influence of environmental and genetic factors on the phenotype was studied by rearing plants under rather uniform conditions in an experimental garden from representative samples of seed collected from populations in the field. 


\subsection{The seed}

\subsubsection{Variation in individual plants}

According to Heukels-Van Ooststroom the seeds of S.media are normally provided with a broad wing, but sometimes a few of the uppermost seeds in a capsule may be unwinged. Upon a closer examination (at magnifications of about $\times 40$ ) there appear to be all possible transitions from seeds with a very broad wing to completely unwinged ones. Table 1 shows a classification of the seeds into three categories based on the width of the wing. The principal types of seeds are shown in $f i g .1 b, c, d, e$, and $f$.

Table 1. The classification of the seeds of S.media according to the width of the seed wing.

\begin{tabular}{llc}
\hline Symbol of class & Degree of development of the seed wing & Width of the wing in mm \\
\hline urw & unwinged to rudimentary winged & $0-0.15$ \\
nw & narrowly winged & $0.15-0.30$ \\
bvw & broadly to very broadly winged & $>0.30$
\end{tabular}

After some preliminary results obtained from studies of samples taken from a few populations, the variation in the degree of development of the winged margin of the seed was more accurately recorded, the estimations always being made of seeds of the capsules first formed on the dichasial cymes (i.e. of the proximal capsules) and of seeds of the last-formed capsules of the inflorescences (i.e. of the distal capsules). On account of the large number of seeds per capsule a visual estimate was made of the percentages of the seeds belonging to each of the three above-mentioned categories according to the following scale with 11 ranges of percentages: $9 \%$ or less: $+, 10-19 \%: 1$, $20-29 \%: 2,30-39 \%: 3, \ldots . .90-99 \%: 9,100 \%: 10$. The representation of the results of the estimations is as follows: behind the number of the plant the position of the capsule is indicated (proximal or distal) and behind the colon the number of capsules examined is given and, in brackets, the type of seed and the number indicating the percentage: " 3 (bvw 9 urw +)" means that in 3 capsules $90-99 \%$ of the seeds had broad to very broad wings and $0-9 \%$ unwinged to rudimentary winged seeds.

From the 43 plants studied, 654 capsules of the proximal parts of the inflorescence and 218 of the distal parts were gathered and their seeds examined. The variation being rather similar in many plants, only a few characteristic cases are shown here:

Plant M 6103, prox.: 13 (bvw 10)

$$
\text { , , dist.: } 16 \text { (bvw 10) }
$$

Plant M 6127, prox.: 5 (bvw 10); 7 (bvw 9 nw + urw +); 5 (bvw 9 urw +);

2 (bvw 7 nw + urw 1); 1 (bvw 5 nw + urw 3)

" , dist.: 2 (bvw 9 nw + urw + ); 1 (bvw 9 urw +); 1 (bvw 8 


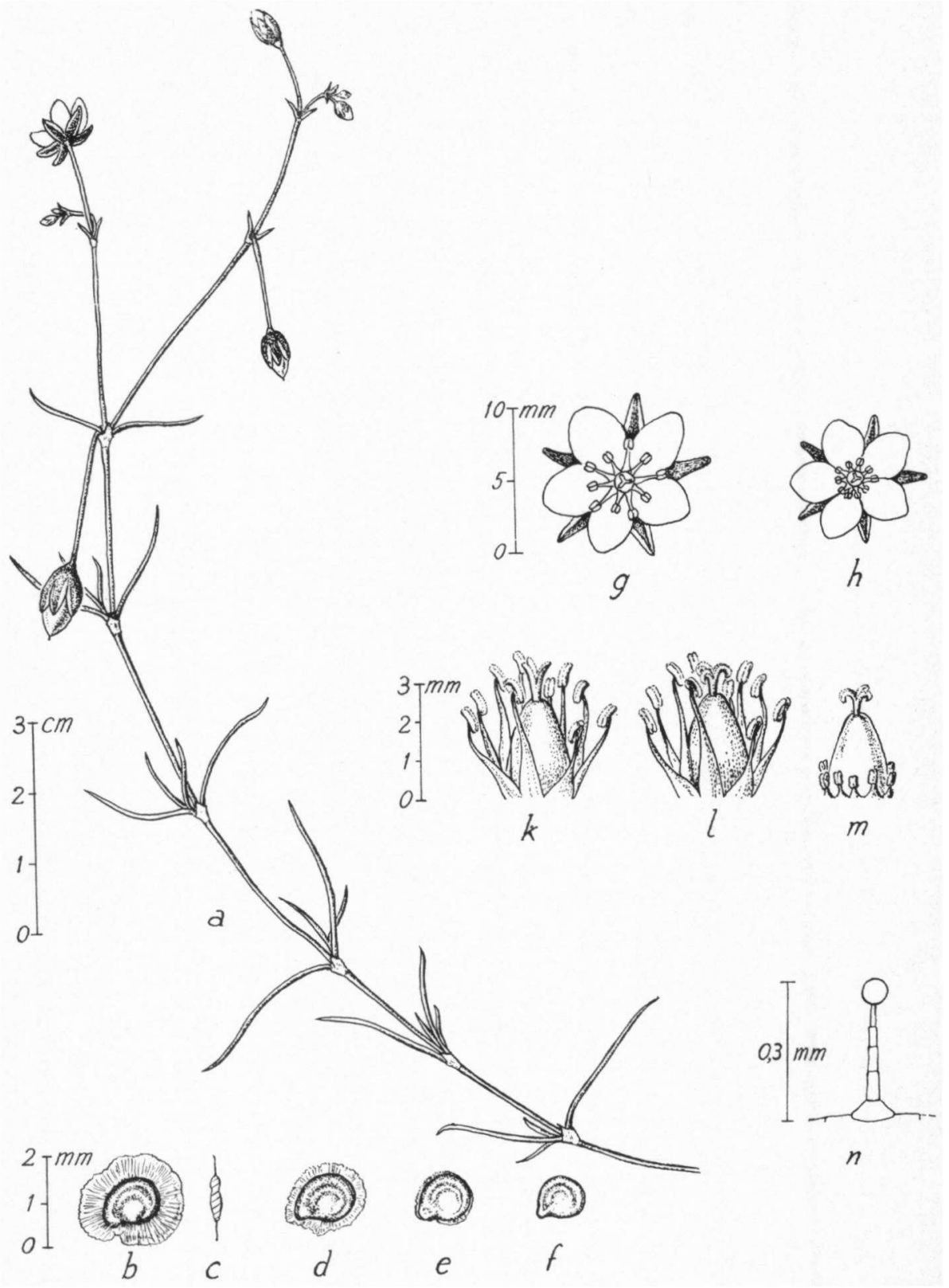

Fig. 1. S. media. a. habit; b. and c. broadly winged seed; d. narrowly winged seed; e. rudimentary winged seed; f. unwinged seed; g. flower with fertile stamens; h. flower with staminodes; $\mathbf{k}$. androecium and pistil with erect and somewhat spreading stigmas; 1. idem with spreading and recurved stigmas; $m$. pistil and reduced androecium; $n$. glandular hair. 


$$
\begin{aligned}
& \text { nw }+ \text { urw 1); } 1 \text { (bvw } 6 \text { nw } 2 \text { urw 1); } 1 \text { (bvw } 6 \text { nw } 1 \\
& \text { urw 2); } 2 \text { (bvw } 6 \text { nw }+ \text { urw 2); } 1 \text { (bvw } 5 \text { nw } 3 \\
& \text { urw 1); } 1 \text { (bvw } 5 \text { nw }+ \text { urw 4); } 1 \text { (bvw } 5 \text { nw }+ \\
& \text { urw 3); } 1 \text { (bvw } 4 \text { nw }+ \text { urw 4); } 2 \text { (bvw } 3 \text { nw } 3 \\
& \text { urw 2); } 1 \text { (bvw } 3 \text { nw } 2 \text { urw 4);1 (bvw } 2 \text { nw } 3 \\
& \text { urw 3); } 1 \text { (bvw } 1 \text { nw } 2 \text { urw 5); } 1 \text { (bvw } 1 \text { nw } 1 \\
& \text { urw 6); } 1 \text { (bvw + nw } 5 \text { urw 4);1 (nw + urw 9) }
\end{aligned}
$$

Plant M 6123, prox.: 2 (nw 10); 9 (nw 9 urw + ); 4 (nw 8 urw 1)

" , dist.: 2 (nw 9 urw +); 1 (nw 8 urw 1); 1 (nw 6 urw 3);

2 (nw 5 urw 4); 1 (nw 4 urw 5); 5 (nw 2 urw 7);

3 (nw 1 urw 8)

Plant M 2058, prox.: 15 (urw 10)

$$
\text { ", dist.: } 15 \text { (urw 10) }
$$

In 16 out of the 43 specimens examined the predominant type of seed was bvw, the categories of 250 proximal capsules taken from these 16 plants being distributed as follows: 192 (bvw 10), i.e. $77 \% ; 46$ (bvw 9), i.e. 18\%; 2 (bvw 8), i.e. $1 \% ; 4$ (bvw 7), i.e. $2 \%$; and 6 , i.e. $2 \%$, with fewer than $70 \%$ bvw-seeds.

In 19 out of these 43 plants the predominant seed type was urw, the distribution of the 316 distal capsules of the 19 specimens in question being as follows: 290 (urw 10), i.e. $91 \% ; 21$ (urw 9), i.e. $7 \% ; 3$ (urw 7), i.e. 1\%; and 2, i.e. $1 \%$, with fewer than $70 \%$ urw-seeds. These quantitative data show that the individual specimens, in their proximal capsules, exclusively or predominantly produce seeds of only one seed class and on the basis of this criterion three types of plants can be distinguished, viz., "BVW-plants", „NW-plants" and "URW-plants", but one should bear in mind that this is a grouping of a series of plants exhibiting a continuous variation of the width of the seed wing.

A comparison of the seeds of the most proximally produced capsules with those of the most distally produced ones shows that in all cases in which there are any differences, the seeds of the more distally situated capsules consistently contain a higher percentage of the nw- and urw-types of seeds than the more proximally produced ones. This phenomenon appears to be concomitant with a decrease in the number of viable seeds and of the overall length of the seeds as the capsule matures later (i.e. more distally) on the plant, and this coincidence strongly suggests that the conditions for the production of fruits and seeds are less favourable in the distal portions of the inflorescence than they were in the beginning (when the proximal capsule was formed). A possible explanation is the unequal rate of supply of nutrients in the young inflorescences and in its ultimate terminal ramifications. Within a single capsule a similar "gradient" is observed. If a plant produces capsules containing seeds of different types, the seeds with the best developed (broadest) wings are nearly always found in the basal part of the central placenta, and this is, likewise, suggestive of a more privileged position of the parts closer to the source of nutrients. 
2.2.2. Variation within populations

Capsules hailing from 21 populations in the south-western part of the Netherlands and from 19 populations in the northern part were studied by repeated sampling in 1959, 1963, 1964 and 1965 . The localities are indicated on the maps of these parts of the Netherlands shown in figs. 2 and 3. After a study of the variation per plant the capsules were classified in 3 categories, viz. BVW, NW and URW with over $70 \%$ of bvw-, nw- and urw-seeds, respectively.

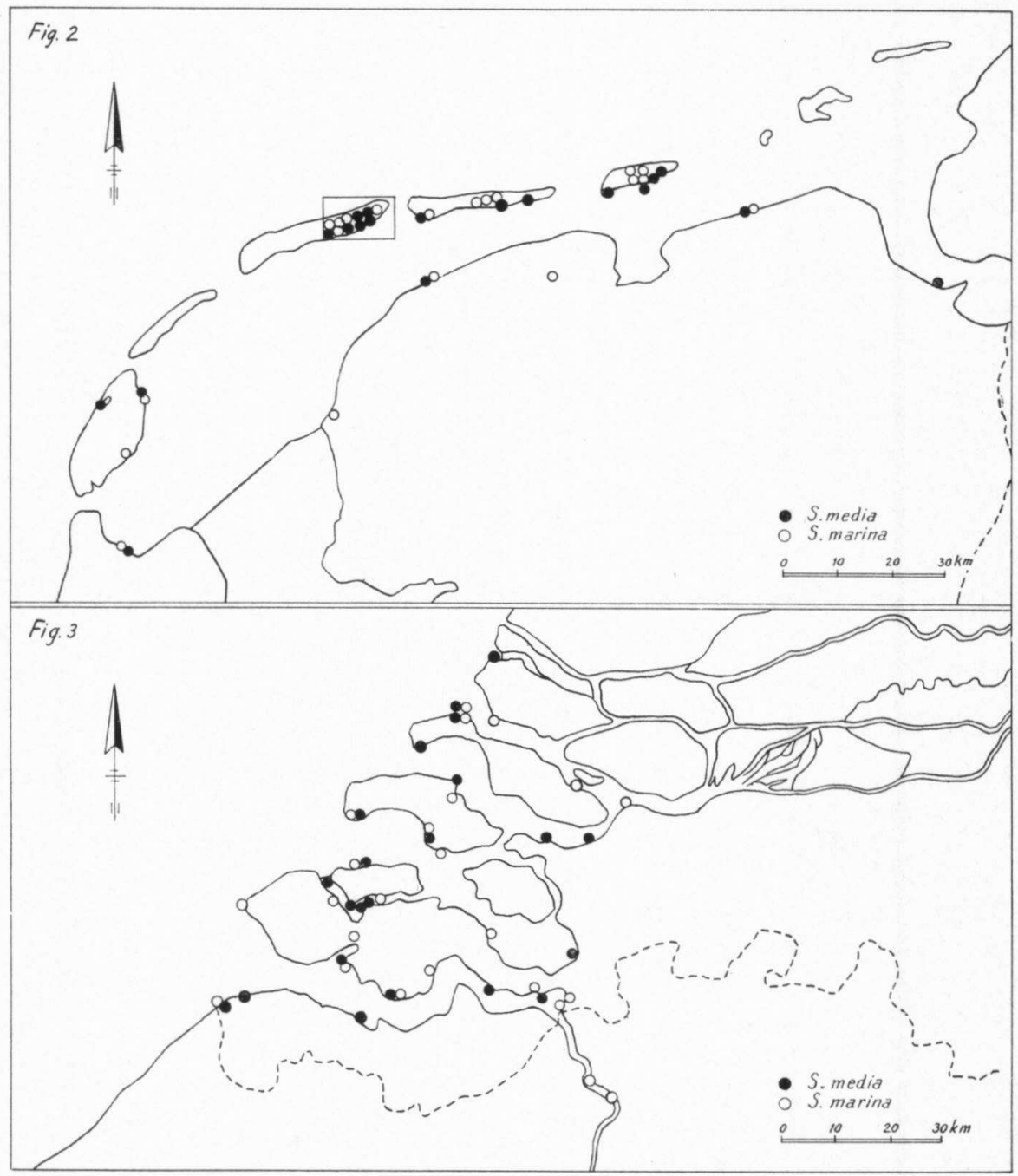

Fig. 2. and 3. Map of N-Netherlands (fig. 2, above) and map of SW-Netherlands (fig. 3, below) showing the localities of the investigated populations. 
Table 2. Some characteristic frequency distributions of the three capsule types of the population samples of the south-western and northern part of The Netherlands:

Bos. = Boschplaat, n.o.d. = north of the dunes, O.kw. = Oosterkwelder, Schier. $=$ Schiermonnikoog, sm. = saltmarsh, s.o.d. = south of the dunes, St.P. = SintPhilipsland, Ter. = Terschelling, Z-Bev. = Zuid-Beveland, Z.-VL. = ZeeuwsVlaanderen.

\begin{tabular}{|c|c|c|c|c|}
\hline \multirow{3}{*}{ Locality of population } & \multirow{3}{*}{$\begin{array}{c}\text { Number } \\
\text { of } \\
\text { capsules }\end{array}$} & \multirow{2}{*}{\multicolumn{3}{|c|}{$\begin{array}{c}\text { Percentage of capsules } \\
\text { Capsule type }\end{array}$}} \\
\hline & & & & \\
\hline & & URW & NW & BVW \\
\hline Zwin, Z.-VL. & 140 & & 1 & 99 \\
\hline sm. of de Heene, St. P. & 148 & 3 & 12 & 85 \\
\hline Springersgors, Ouddorp, Goeree & 150 & 10 & 69 & 21 \\
\hline Kwade Hoek, Goeree, dune valley & 150 & 21 & 30 & 49 \\
\hline Kwade Hoek, Goeree, saltings & 150 & & 16 & 84 \\
\hline Groene Strand, Oostvoorne & 147 & 28 & 59 & 13 \\
\hline Slufter, Texel & 184 & 71 & 17 & 12 \\
\hline Grie, Ter. & 150 & & 2 & 98 \\
\hline Groede, Ter. & 150 & 3 & 8 & 89 \\
\hline Bos. near mark 23 s.o.d., Ter. & 150 & 11 & 12 & 77 \\
\hline Bos. near mark 25 s.o.d., Ter. & 150 & 17 & 5 & 78 \\
\hline Bos. near mark 23 n.o.d., Ter. & 150 & 20 & 21 & 59 \\
\hline Bos. near mark 26 n.o.d., Ter. & 150 & 30 & 16 & 54 \\
\hline sm. near Hollum, Ameland & 148 & 76 & 13 & 11 \\
\hline Nieuwlandsrijd, Ameland & 148 & 35 & 18 & 47 \\
\hline De Hon near mark 23a, Ameland & 141 & 48 & 19 & 33 \\
\hline Westerkwelder, Schier. & 150 & 8 & 18 & 74 \\
\hline O. kw. near mark $T$, Schier. & 150 & 13 & 16 & 71 \\
\hline O. kw. between mark R-S. Schier. & 150 & 32 & 22 & 46 \\
\hline O. kw. near mark $P$, Schier. & 150 & 44 & 22 & 34 \\
\hline Balgzand, S.E. of Den Helder & 145 & 5 & 10 & 85 \\
\hline
\end{tabular}

Not all capsules could be classified in this way, however. In a very large majority of the populations the percentage of such unclassifiable capsules is less than $5 \%$ and the overall picture of the variation is not appreciably affected by the presence of such capsules.

Table 2 shows some characteristic relative frequency distributions of the samples collected in the two areas.

The considerable variation in the degree of development of the wing of the seed margin is striking. In a majority of the samples all three types of capsules (BVW, NW and URW) are represented. It is also quite clear that there are considerable differences between the populations sampled in the northern and in the southern part of Holland. Roughly speaking, URW-capsules are of fairly common occurrence in the northern region, whereas they are rare in the south-western area. In the northernly populations the lowermost percentages of URW-capsules were recorded in populations on clayey salt marshes such as the Grie and the Groede (Terschelling), the Westerkwelder (Schiermonnikoog) 
and the Balgzand SE of Den Helder, and the highest in populations growing on sandy beaches such as De Slufter (Texel), the Boschplaat N. of the dunes (Terschelling) or at sandy sites in the transitional zones between salt marshes and sandy beaches found in, e.g. Ameland (near Hollum and at De Hon) and Schiermonnikoog (Oosterkwelder near the beach marker pole P). In the southwesternly area the highest relative frequencies of URW-capsules were encountered in samples from populations from the Groene Strand (Oostvoorne), the Kwade Hoek (Goeree) and the Springersgors (Goeree), which sites ecologically resemble the last-mentioned northern localities rather closely in, $e$.g., their sandy soil and their sparse stands of vegetation. The preliminary conclusion may be drawn that there is a correlation between the relative frequency of occurrence of the BVW-and the URW-types of capsules and the environmental conditions. There is not such a clear correlation between the percentage of capsules of the NW-type and the environment, however (see STERK 1968, p. 26).

In order to obtain an insight into the influence of the genetic predisposition and the environmental factors on the degree of development of the seed wing, progeny was reared from seeds of capsules of the types BVW, NW en URW obtained from natural populations in the field. These experiments showed quite convincingly that the degree of seed wing development is primarily determined by genetic factors (STERK 1968). The direct influence of the external environment on the phenotypic expression of the genetic factors was investigated by means of a comparative analysis of the progenies of plants of the type BVW reared on different substrata, viz., on a rich soil (clay enriched with inorganic nitrogen) and on a poor soil (one part of clay on 10 parts of sand). The counts of the relative numbers of seeds of the type urw in the progenies reared on the rich and on the poor soil appear to differ significantly and this experiment indicates that plants growing in a more fertile soil produce fewer seeds of the urw-type than plants rooting in a poor soil. Experiments carried out in the field by sowing seeds of plants of the URW-type at sites where URW-plants do not naturally occur were unsuccessful; seeds gathered from the BVWplants growing at these sites and sown in the same places where the 'extraneous' ones were strewn about did not develop either. Transplantation experiments performed bij planting URW-type seedlings at sites where only BVW-plants grow naturally, did not yield any positive results either; transplanted seedlings of the local stand of BVW-plants also died prematurely. Experiments of both kinds carried out at natural sites prove to meet with many practical difficulties, especially in coastal areas affected by tidal movements where the environmental factors fluctuate a great deal.

\subsubsection{Size of seeds and seedlings}

Of a number of representative seed samples of natural populations the overall dimensions of the seed body (without the wing) of seeds of the bvw-, nw- and urw-types were determined. The "size" of these seeds was expressed by means of the dimensions $a$ (greatest length) and $b$ (greatest width), measured as shown in fig. 4. 
Fig. 4. S. media. The "size" of the seed measured according to a and b.

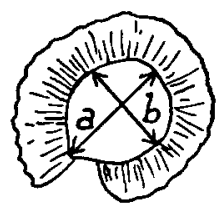

For a statistical analysis $a$ and $b$ were added and the seeds were arranged in "size" classes according to the values of $(a+b)$ as follows: class 1 ranging from $0.98 \mathrm{~mm}$ to $1.10 \mathrm{~mm}$, class 2 from $1.10 \mathrm{~mm}$ to $1.22 \mathrm{~mm}$, etc. The "size" variation of the different types of seeds is shown in fig. 5 .

It is evident from the diagrams that there is a relation between the "size" of the seed body and the width of the seed wing, the urw-type of seed upon the average being smaller than the seeds of the nw-type, and the latter in turn smaller than the bvw-seeds. The mean weight of the various seed classes also differs, the mean weight of 1,000 urw-seeds being $0.088 \mathrm{~g}$, and that of $1,000 \mathrm{bvw}$-seeds $0.107 \mathrm{~g}$; the urw-seeds are apparently lighter than the bvw-seeds.

In order to establish the possible relation between seed size and seedling size, the dimensions of the hypocotyl and the cotyledons of 50 seedlings reared from urw-seeds and of 50 reared from bvw-seeds were determined. The differences between the mean length and diameter of the hypocotyls and between the mean length and breadth of the cotyledons of seedlings reared from urw-seeds and bvw-seeds, respectively, are diagramatically represented in fig. 6 .

The seedlings developing out of seeds of the bvw-type are, generally speaking, appreciably larger than those raised from urw-seeds.

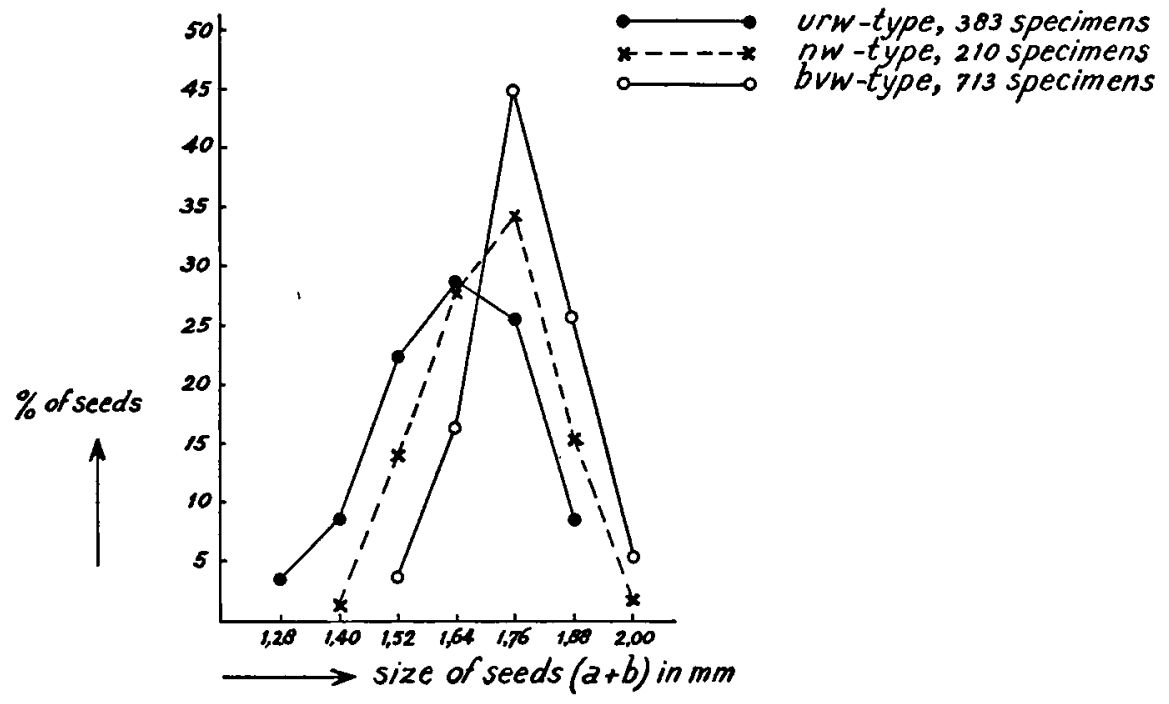

Fig. 5. S. media. Relation between the "size" of the seed body and the width of the seed wing. Acta Bot. Neerl. 18(2), April 1969 
Fig. 6. $S$. media. The relative size of the overground part of the seedlings of bvw-seeds (a) and urw-seeds (b).
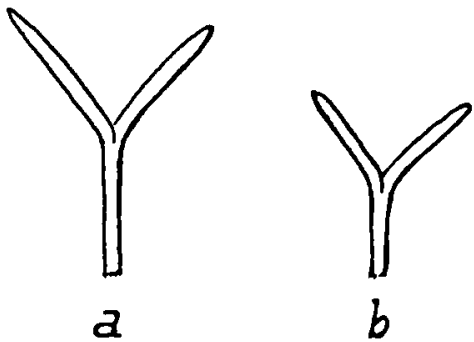

2.3. Length of fruit and calyx and the number of seeds per capsule 2.3.1. Length of fruit and calyx

The ratio between the length of the fruit and the length of the calyx is often used as a diagnostic character to distinguish S.media and S.marina. The excursion flora of Heimans, Heinsius and Thijsse states that in S.marginata (=S.media Presl) the capsule is much exserted from the calyx, and that in $S$ salina and S.media Fr. (in the present paper both included in S.marina) the capsule is not much longer than the calyx.

In 8 representative samples of populations the lengths of fruit and calyx and the ratio fruit length/calyx length were determined. The results indicate that the differences in frequency distribution found between populations are associated with the percentage of URW-capsules in the samples. The individual samples of wild populations will not be discussed in the present context and only a survey of the length of the calyx and the lengths of capsules of the BVW-, NW- and URW-types is given in table 3.

Table 3. S. media. The length of fruit and calyx of BVW-, NW- and URW-capsules.

\begin{tabular}{|c|c|c|c|c|c|c|c|c|c|c|c|}
\hline \multirow{2}{*}{ Organ } & \multirow{2}{*}{$\begin{array}{c}\text { Capsule } \\
\text { type }\end{array}$} & \multirow{2}{*}{$\begin{array}{l}\text { Number } \\
\text { of organs } \\
\text { examined }\end{array}$} & \multicolumn{9}{|c|}{$\begin{array}{c}\text { Percentage } \\
\text { Length in } \mathrm{mm}\end{array}$} \\
\hline & & & 2 & 3 & 4 & 5 & 6 & 7 & 8 & 9 & 10 \\
\hline \multirow[t]{3}{*}{ fruit } & BWV & 979 & & & & 6.1 & 22.6 & 38.3 & 28.2 & 4.3 & 0.5 \\
\hline & NW & 303 & & & 5.3 & 22.1 & 37.6 & 27.1 & 7.6 & 0.3 & \\
\hline & URW & 351 & & 0.3 & 18.8 & 46.2 & 23.6 & 9.7 & 1.4 & & \\
\hline \multirow[t]{3}{*}{ calyx } & BVW & 979 & 0.6 & 9.2 & 39.6 & 43.4 & 7.1 & 0.1 & & & \\
\hline & NW & 303 & 0.3 & 8.7 & 51.4 & 35.9 & 3.7 & & & & \\
\hline & URW & 351 & 0.6 & 10.7 & 62.3 & 22.8 & 3.6 & & & & \\
\hline
\end{tabular}

It is clear from this table that capsules of the BVW-type are on the average longer than those of the URW-type and that the capsules of the NW-type are intermediate in this respect. The mean fruiting calyx length of BVW-capsules differs significantly from that of the URW-capsules (for detail, see STERK 1968). Capsules of the BVW-type are mostly more exserted from the fruiting 
calyx than those of the URW-type. The statistical analysis reveals that also in "S. marginata" capsules which are only a little longer than their fruiting calyces are of frequent occurrence, so that the large range of overlap renders the differential diagnostic value of the ratio capsule length/calyx length quite inadequate to separate $S . m e d i a$ from S.marina.

\subsubsection{Number of seeds per capsule}

From comparative cultivation experiments in the experimental garden and in greenhouses the conclusion could be drawn that the number of seeds per capsule of BVW-plants does not differ significantly from that of URW-plants. Of $272 \mathrm{BVW}$-capsules gathered from cultivated plants the mean number of seeds per capsule was 86, and of 163 URW-capsules that number was 90 .

\subsection{The number of stamens per flower}

\subsubsection{Variation in individual plants}

In many floral works the average number of stamens per flower is used as an important differential character to segregate S.media and S.marina. According to the flora of Heukels-Van Ooststroom 10 stamens are found in the flowers of S.media as against 3-5 (-8) stamens in those of S.marina. After rather extensive preliminary studies of a few selected populations the variation of the number of stamens per flower was more accurately determined in lots of 30 individual plants, the flowers being grouped in 10 classes on the basis of the number of fertile stamens they contain. The variation in the number of fertile stamens per flower in 5 representative specimens of S. media is shown in table 4.

Table 4. S.media. The number of stamens per flower of 5 characteristic plants.

\begin{tabular}{|c|c|c|c|c|c|c|c|c|c|c|c|c|}
\hline \multirow{3}{*}{ No. of plant } & \multicolumn{11}{|c|}{ Percentage of flowers } & \multirow{3}{*}{$\begin{array}{c}\text { Total } \\
\text { number of } \\
\text { flowers }\end{array}$} \\
\hline & \multicolumn{11}{|c|}{ Number of stamens per flower } & \\
\hline & $\mathbf{0}$ & 1 & 2 & 3 & 4 & 5 & 6 & 7 & 8 & 9 & 10 & \\
\hline M 205 & & & & & & & & & & 2.0 & 98.0 & 51 \\
\hline M 216 & & & & 2.3 & & 2.3 & & & 2.3 & 6.8 & 86.3 & 44 \\
\hline M 217 & 7.0 & 1.8 & 1.8 & 3.4 & & 1.8 & & & 7.0 & 7.0 & 70.2 & 57 \\
\hline M 209 & 79.5 & 5.4 & 1.1 & 4.3 & 1.1 & & 1.1 & & 1.1 & & 6.4 & 93 \\
\hline M 207 & 99.0 & & & 1.0 & & & & & & & & 101 \\
\hline
\end{tabular}

It appears that plants may exhibit considerable differences in the variation of the number of androecial elements. These differences are caused by a different degree of reduction of the androecium, the number of fertile stamens varying from 1 to 10 but the total number of fertile stamens plus staminodia always amounting to 10 (or exceptionally to 9 ). The reduction can progress so far that the plant does not produce a single flower with one or two whorls of fertile 
stamens; an extreme example is plant M 207 which produced almost exclusivele flowers without any fertile stamens (only 1 out of 101 flowers contained 3 fertiyl stamens). Even the most commonly occurring type of plant such as M 205 sometimes bears a few flowers with one of their stamens reduced to a staminode or completely lacking. It is striking that the individual plants produce either predominantly normal flowers or chiefly flowers with staminodes. Plants bearing mainly flowers with 4, 5 or 6 fertile stamens (and the corresponding number of staminodia) have not been encountered. In cultivated specimens occasionally flowers with 11 fertile stamens were encountered.

By cultivation of plants from seeds of specimens with predominantly staminodial androecia it could be demonstrated that the reduction of the androecium in plants of the types M 209 and M 207 is genetically determined.

Flowers with strongly reduced androecia almost invariably contain a welldeveloped pistil and produce viable seeds, but in S.media also flowers with pistillodes occur very rarely among flowers with normal gynoecia on the same plant.

\subsubsection{Variability within populations}

In the northern parts of our country 10 populations of $S$. media were studied and 9 in the south-western area. Of each population a representative lot of 100-150 flowers was examined in 1959, 1963, 1964 and 1965. The localities where these populations occur are indicated on the maps of the two areas shown in fig. 2 and 3. Table 5 shows two relative frequency distributions which are representative of the samples of flowers (for the exact localities of the other populations studied, see STERK 1968, p. 38).

Table 5. S. media. The relative frequency distributions of the number of stamens per flower of 2 representative population samples.

\begin{tabular}{|c|c|c|c|c|c|c|c|c|c|c|c|c|}
\hline \multirow{3}{*}{ Locality } & \multicolumn{11}{|c|}{ Percentage of flowers } & \multirow{3}{*}{$\begin{array}{l}\text { Number of } \\
\text { flowers }\end{array}$} \\
\hline & \multicolumn{11}{|c|}{ Number of fertile stamens per flower } & \\
\hline & $\mathbf{0}$ & 1 & 2 & 3 & 4 & 5 & 6 & 7 & 8 & 9 & 10 & \\
\hline
\end{tabular}

Spieringschor,

N-Beveland

Boschplaat

near mark 26

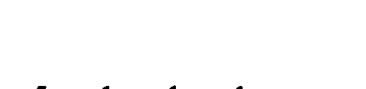

$5 \quad 1-1 \quad 1$

$\begin{array}{rrrrrrr}1 & & 1 & 3 & 9 & 86 & 100 \\ 1 & 2 & 3 & 3 & 13 & 70 & 100\end{array}$

Flowers with 10 well-developed stamens appear to be of most frequent occurrence by far in both types of populations shown in table 5. Flowers with 9 fertile stamens are not rare in nearly all population samples; in 11 out of 19 samples their representation exceeded $10 \%$. Flowers with 8 fertile stamens are rare and the flowers with increasingly fewer fertile stamens become rarer as the 
androecial reduction progresses. Within the population samples those from the Groede and the Boschplaat (Terschelling) are conspicuous in that the percentage of flowers with completely sterile androecia is relatively high; such flowers occur on plants of the types M 209 and M 207 of table 4 which are relatively numerous in these two localities.

\subsection{Growth habit and length of leaves and internodes}

In S.media the mode of branching, and the length of the stems, leaves and internodes varies a great deal. The habit form is largely decided by the density of the stand of vegetation. In sparsely developed vegetation strongly ramified plants with prostrate to ascending stems occur, the main branching of the stems taking place in their lowermost nodes and the branches radiating from the centre of ramification. In such plants the internodes and leaves are rather short. At repeatedly inundated and sand-blown sites, even in sparse vegetation, a system of ramification develops which resembles that of plants from dense stands. In close stands the plants are much more erect and their basal internodes are only sparsely branched; their stems, leaves and internodes are usually longer than those of prostrate plants of 'open' sites. All possible transitions between the prostrate growth form of sparse stands and the erect form of 'closed' stands occur.

When seeds taken from both habit forms were sown in our experimental garden, the differences between the prostrate habit form of sparse vegetation and the erect habit form of dense stands disappear. The differences in habit are clearly caused by environmental conditions and cultivation experiments have shown that the factor 'light' is of primary importance as could be expected.

$S$. media is perennial, the overground parts dying off in the cold season and the lowermost stem nodes and root system hibernating. The perennial parts produce periderm and assume a corky-brown and "woody" appearance. The species is very well adapted to being covered by sand and clay deposited by sedimentation or blown in. On the higher cliff-like edge of the saltings of the Grie (Terschelling) plants were dug up whose hypocotyl region was $15 \mathrm{~cm}$ below the surface of the soil. The buried branches often produce adventitious roots and occassionally plants are encountered whose main tap root has died off but whose uppermost parts were green and fruit-bearing, the task of the principal root having been taken over by the adventitious ones. The adaptation to becoming covered by deposited sand and clay is of course an essential requisite for species occurring in sites where sedimentation takes place continually.

Plants of S.media growing in a sandy soil develop an extensive and strongly ramified root system of a pale brown colour; plants of a clayey habitat form a less ramified root system in which the main root is usually much more conspicuous.

On account of the considerable variation in their shape and dimensions the characters of the stems and leaves are of little diagnostic significance. A biometrical analysis did not reveal any significant differences in the length of the internodes and the leaves of BVW- and URW-plants. 


\section{ACKNOWLEDGEMENTS}

This paper, the first of a series of four, represents parts of the thesis for a Dr. Phil. degree, prepared under the guidance of Prof. J. Lanjouw, State University, Utrecht. The author is much indebted to Prof.A.D.J. Meeuse, Hugo de Vries-Laboratorium, University of Amsterdam, who is responsible for the English translation.

\section{REFERENCES}

Clapham, A. R., T. G. Tutin \& E. F. Warburg (1962): Flora of the British Isles, ed. 2: 260-261. Cambridge.

HEGI, G. (1964): Illustrierte Flora von Mittel-Europa, III, 2: 786-789.

Heimans, E., H. W. Heinsius \& J. P. ThiJsse (1965). Geillustreerde Flora van Nederland, ed. 21 (by J. Heimans): 340-341. Amsterdam.

Heukels, H. \& S. J. van Ooststroom (1962): Flora van Nederland, ed. 15: 206. Groningen.

Holkema, F. (1870): De plantengroei der Nederlandsche Noordzee-eilanden: 38-40. Amsterdam.

LAWALrEe, A. (1952): Flore générale de Belgique I, 1: 374-377. Bruxelles.

MARSSON, Th. Fr. (1869): Flora von Neu-Vorpommern und den Inseln Rügen und Usedom: 77-78. Leipzig.

MONNIER, P. (1953): Sur quelques spergulaires du Maroc appartenant au groupe de Spergula marginata (DC.) Murb. Rec. trav. lab. Bot. Geol. Zool., série Bot. 6: 77-88. Montpellier.

- (1955): Introduction à une révision du genre Spergularia (Pers.) Presl au Maroc. Bull. Soc. Sc. nat. et Phys. du Maroc 35: 145-163.

- (1960a): Biosystématique de quelques Spergularia méditerranéens. Compt. rend. l'Ac. Sc. 250: $4429-4431$.

- (1960b): Biosystématique de quelques Spergularia méditerranéens. Compt. rend. l'Ac. Sc. 251: $117-119$.

- (1962): Biogéographie et micro-évolution chez Spergularia marginata Kittel dans le bassin méditerranéen occidental, Afrique du Nord notamment. Rev. Cyt. Biol. Vég. XXV, 3-4: 325-335.

RATTER, J. A. (1959): A cytogenetic study in Spergularia. Thesis.Liverpool.

- (1964): Cytogenetic studies in Spergularia I. Notes Royal Bot. Gard. XXV, 3: 293-302. Edinburgh.

- (1965): Cytogenetic studies in Spergularia II. Notes Royal Bot. Gard. XXVI, 2: 203-236. Edinburgh.

ROTHMALER, W. (1963): Exkursionsflora von Deutschland. Krit. Ergänzungsband Gefässpfl.: 121. Berlin.

STERK, A. A. (1968): Een studie van de variabiliteit van Spergularia media en Spergularia marina van Nederland. Thesis Utrecht: 1-156. Tilburg.

WESTHOFF, V. (1947): The vegetation of dunes and salt marshes on the Dutch islands of Terschelling, Vlieland and Texel. Thesis Utrecht.

- \& BROUWER, G. A. (1951): De natuurwetenschappelijke betekenis van het staatsnatuurmonument de Boschplaat op Terschelling. Amsterdam. C.C. voor Natuur- en Landschapsbescherming. 